\title{
THE STREPTOCERA GROUP OF THE DIPTEROUS GENUS TIPULA LINNAEUS.
}

\author{
W. G. Dietz, M. D.
}

A natural group of species, which briefly may be characterized as follows: Wings approximately unicolorous, stigma distinct, the antestigmal spot always extends into cell 1st M2, but is interrupted in the outer end of cell $\mathrm{R}$ in most of the species. The eighth sternite of the male is prolonged and narrowed posteriorly, except devia. The hypopygium is of moderate size. The ninth tergite, generally small, is emarginate in the middle, except fragmentata. The pleural suture is distinct, except devia - the pleurite prolonged into a process, generally long and twisted, hornlike, rarely into an acutely pointed cone, derbyi, or simply tipped by a sharp point, devia. The ovipositor is very short, the upper valves generally rounded or oval, in some species ending in a downward curved point, giving thus a beaklike appearance; the lower valves scaphoidal. In all the specimens in my collection, the posterior end of the abdomen, especially the males, is curved upward and sometimes backwards towards the abdominal tergum. Whether this also obtains in the living insect I have no means to know.

The species, below medium in size, are yellowish to testaceous in color, with more or less lustre. They resemble each other very closely and the genital structure of the males must in almost all cases be depended upon for differentiation.

\section{KEY TO THE SPECIES.}

1. Joints of the antennal flagellum unicolorous. Western species............2 Flagellar joints bicolored. Eastern United States; aberrant form.

2. The ninth tergite of the male distinctly emarginate..................... Not as in the alternative...................... fragmentata spec. n.

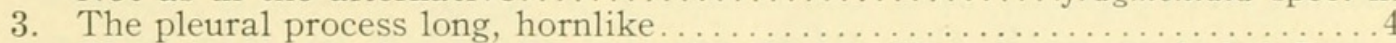
The pleurite prolonged into a pointed, conelike process.... derbyi Doane

4. The pleural process long, twisted, more or less curved, glabrous...........5 The process shorter, approximately straight, stiletto-like, hairy,

5. Process conspicuously curved...

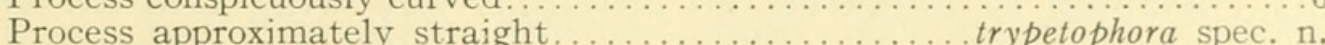

6. The ninth tergite with a deep, oval emargination, the sides prolonged into converging processes, the inner margin with a conspicuous tooth.

Not as above.

opisthocera spec. $\mathrm{n}$

7. Process shorter, viewed laterally, much wider in basal half. .mutica spec. $\mathrm{n}$. Not as in the alternative.

8. Antennal flagellum-except basal joint-dark brown

streptocera Doane Antennæ entirely yellowish . var. streptocera pallidocera var. n. 


\section{Tipula devia sp. nov.}

Yellow. Antennæ yellow, flagellar joints beyond the third, brown at the base. Thoracic stripes obsolete. Pleurite of hypopygium tipped with a sharp point.

Male, length 13 millimeters, wing 14.5 millimeters.

Head entirely, together with mouth-parts and palpi, yellow; last joint of palpi a trifle longer than the three preceding joints together. Antennæ yellow, flagellar joints beyond the third brownish at the base; joints cylindrical, basal enlargement very slight, the setæ about as long as the respective joints. Thorax concolorous, dorsum subtranslucent, stripes obsolete, pleura with a faint whitish sheen, coxæ and trochanters yellow, rest of legs lost. Halteres pale yellow, club infuscate. Wings light gray, costal cells yellow, stigma light fuscous, veins $\mathrm{C}, \mathrm{S} \mathrm{C}, \mathrm{R}$ and $\mathrm{Cu}$, yellow, the other veins brown; the antestigmal spot strongly marked, extending through cell 1st M2 into base of cell M3. As far as I can perceive, vein M1 and M2 alone are distinctly setigerous, the setæ rather long.

Abdomen yellow, darker posteriorly, the eighth sternite very little prolonged, the posterior margin with a median notch and a slight emargination on each side; a dense brush of golden-yellow, bristly hair arises from beneath the margin and a stout bristle, curved outward from the lateral angle. Hypopygium .(P1. V, Figs. 1 and 2) testaceous. Ninth tergite markedly narrowed posteriorly, deeply emarginate, the upper surface impressed mesially, the sides of the tergite prolonged into an acute process, denticulate within. Ninth sternite broadly emarginate, base of the emargination subangulate. Pleural suture obsolete, the pleurite projects as an acute point. Outer apical appendages large, hatchet-shaped, projecting inward, lower appendages large, sausage-shaped bodies, coarsely hairy and projecting downward into the emargination of the ninth sternite.

Holotype, $\sigma^{7}$. Plummers Island, Maryland, June 28th, 1914 (W. F. McAtee).

A distinct, but somewhat aberrant species in this group. The absence of the pleural suture, the pleurite merely projecting into an acute point and the scarcely prolonged eighth sternite is at variance with the other species included in this paper. It is the only species with bicolored antennal flagellum and the only one from the Eastern United States. The type and only specimen is defective, an antenna, one wing and all the legs wanting.

Note:- Since the above has been written, three more specimens of this species have turned up in my collection. A male, Southern Pines, North Carolina, June, 1910, (A. H. Mance); a male and female specimen, Black Mountain, North Carolina, July, 1912, (Wm. Bentermueller). 
Allotype, o , has the ovipositor elongated, testaceous and highly polished. The upper valves long and slender, pointed. The lower valves nearly four-fifths the length of the upper valves, obtuse at the apex.

Tipula fragmentata sp. n.

Reddish-brown with some lustre. Thoracic stripes distinct; ninth tergite rounded posteriorly, with a subtriangular prolongation from beneath the posterior margin. Pleural prolongation slender, twisted, strongly inclined proximad.

Male, length 11 millimeters, wing 13.5 millimeters.

Head dark, margin of orbits whitish. Frontal prolongation rather long, reddish-brown, shining, beset with black hairs. Nasus short, obtuse, with a tuft of white hair at the apex. Palpi brown. Scape and first flagellar joint of the antennæ pale yellow, second flagellar joint fuscous, remainder of antennæ wanting.

Thoracic stripes reddish-brown, with some lustre, separated by five yellowish lines of the ground color; the median stripe divided by a fine line. Pleura fuscous, dull. Scutum uniformly dark fuscous with a faint lustre. Scutel yellowish and like the yellowish-fuscous postnotum, shining. Legs slender, yellowish, femora yellow, apices fuscous; tibiæ and tarsi yellowish-fuscous. Halters yellowish, knob wanting. Wings grayish, stigma fuscous, the antestigmal spot faint interrupted in cell 1st, M2; a hyaline spot beyond the stigma.

Abdomen pale testaceous, shining, with median dorsal and lateral stripes, the latter somewhat interrupted; the median stripe does not extend upon the posterior tergites. Hypopygium (Plate XXX, Figs. 3 and 4) yellowish, pleural processes brownish. Ninth tergite rounded posteriorly and from beneath its posterior margin extends a subtriangular process or prolongation. Ninth sternite deeply emarginate, the emarginations almost entirely canceled by the narrowed end of the prolonged eighth sternite, the latter with a brush of hair at its apex. Pleural processes twisted, broad at the base, strongly attenuated and twisted outwardly, inclined towards each other. The outer apical appendage digitiform, extends obliquely inward.

Holotype, $\sigma^{\top}$, bears a label marked California (Bradley), Type C. U.

The specimen is in the collection of Mr. C. P. Alexander. It was received in alcohol and practically dismembered. In its hypopyginal characters, however, more especially the rounded ninth tergite, it is at once differentiated from all the other species. In its distinct thoracic stripes it resembles streptocera, ${ }^{*}$ trypetophora and opisthocera.

* A specimen, labeled $T$. streptocera, received from Prof. Doane, and another from my collection, determined by him, have the thoracic stripes nearly obsolete. The same is also the case in nearly all the specimens of this species in my collection. 
Tipula monochroma spec. n.

Yellowish. Antennal flagellum unicolorous, fuscous. Thoracic dorsum brownish-yellow, dull. Prolongation of pleurite straight, stilletto-like, hairy.

Male. Length 11 millimeters; wing 12.5 millimeters.

Head concolorous; front and occiput gray, with a fine, dark median line. Frontal prolongation long, shining and like the nasus above, beset with short, blackish hairs. Palpi sordid yellow, last joint infuscate and scarcely longer than the preceding joints together. Antennæ moderate, the three basal joints yellowish, the remainder fuscous; segments subcylindrical, the basal enlargement blackish, each with a whorl of black, moderately long setæ.

Thoracic dorsum brownish-yellow; pronotal scutem darker about the middle. Praescutal stripes ill-defined by fine, paler lines. Scutum, scutellum and postnotum semiopaque, slightly more infuscate and somewhat sericeous. Pleura pale yellowish, sericeous. Legs yellowish, outer tarsal joints infuscate, the whole leg beset with coarse, short black hairs. Halters pale, club infuscate. Wings pale grayish; costal cells very pale yellowish; stigma pale, slightly infuscate. The antestigmal spot inconspicuous, extends through cell 1st M2 to base of cell M3, and sending a narrow, pale streak to the wing margin. The veins included in the antestigmal spot are whitish. Veins $R$ and Sc. yellow, the other veins dark brown and delicate. The veins beyond the cord are indistinctly margined with subhyaline. The R, s, and the veins beyond the cord, except those limiting cell 1st M2, setulose.

Abdomen darker yellow, almost testaceous, shining; an ill-defined, more or less interrupted, fuscous dorsal stripe; tergites three to seven with a fuscous spot near the anterior angle and from which extends an indistinct streak along the lateral margin of the tergite. Venter with median blackish stripe, somewhat interrupted and obsolete beyond the fourth sternite. The eighth sternite projecting, narrowed posteriorly, the apical margin nearly truncate, with a brush of stiff, yellowishfuscous, incurved bristles. Hypopygium (P1. V, Figs. 7 and 8) dark testaceous, medium sized. The ninth tergite broad, slightly narrowed posteriorly, the free margin with small V-shaped, median notch, emarginate each side, the apical angles curved downwards. Ninth sternite with a rather deep, V-shaped emargination, from which projects a pencil of stiff bristles, lateral angles with a small appendage, beset with bristles. Pleural suture distinct. The pleural process has the shape of a stilletto, beset with hairs. The outer appendages are yellowish-white, membranous, bilaminate, somewhat protuberant and acuminate; the inner lamina beset with bristles, directed inwardly. Oslar).

Holotype, ๙ $\sigma^{\top}$, Chimney Gulch, Golden, Colorado, (E. J.

Paratype, ๙̋, Silver City, Nevada, June 3rd, 1913.

The paratype is paler than the holotype; the dark markings of the abdomen, with the exception of the lateral spots, nearly obsolete. The hairy stiletto-shaped pleural process of the male will readily distinguish this species. 
Tipula trypetophora spec. n.

Yellowish, testaceous, shining. Antennal flagellum unicolorous. Thoracic stripes distinct. Wings faintly gray, veins beyond the cord broadly margined with hyaline. Pleural process conspicuous, long, twisted, nearly straight.

Male. Length, 13.5 millimeters; wings, 13.5 millimeters.

Head testaceous. Frontal prolongation and rostrum beset with short, black hairs. Palpi fuscous, the last joint scarcely as long as the preceding joints together. Front and occiput fuscous with an obscure, median darker line; the space surrounding the antennal insertion somewhat paler. Antennæ of moderate length; scapal joints pale yellow, first flagellar joint pale yellow at base, infuscate apically, the remaining joints fuscous, cylindrical, basal enlargement with the usual whorl of setæ, the latter shorter than the respective segments; pubescense whitish, very short; the last antennal joints rather strongly attenuate.

Thorax concolorous, shining. Pronotum scarcely darker in the middle. Praescutal stripes brown, well defined, the median stripe very little narrowed posteriorly, the lateral stripes abbreviated in front, extended upon the scutum, leaving a narrow external and internal margin of the ground color. Scutel and postnotum concolorous. Pleura with a pale sheen. Legs yellow, femora somewhat infuscate at the apex; tibiæ darker yellow; tarsi fuscous; tibiæ and metatarsi subequal; pilosity very dense, short, blackish. Halters sordid yellow, club infuscate. Wings grayish-hyaline, costal cells with a faint, yellowish tinge, stigma pale yellowish-fuscous. Veins brown, those beyond the cord broadly margined with hyaline. Cell 1st M2 fully two and one half longer than wide. The antestigmal spot more or less interrupted, extends into cell 1st M2, Rs. and veins beyond the cord, except $\mathrm{Cu}_{1}$, setulose.

Abdomen concolorous; an ill-defined dorsal stripe, more distinct posteriorly; sides of tergites three to eight somewhat infuscate, three to five with a dark fuscous spot near the anterior angle. Venter with illdefined, median darker stripe. The eighth sternite strongly narrowed and prolonged posteriorly, the apical angles with a small, triangular appendage; two narrow processes project from the middle of the posterior margin, the latter without a brush of hair. Hypopygium (P1. V, Figs. 9 and 10) reddish-testaceous and rather large. The ninth tergite short, with narrow median incision, the apex of each side curved dorsad in the form of a small, obtuse tubercle, which is concave and shining on its posterior face. Ninth sternite short, broadly emarginate; pleural suture complete. Pleural process conspicuous, twisted at the base and within the latter arises a sharp, conical process; the direction of the process is nearly straight, caudad; apical appendages inconspicuous.

Female. Length 12.5 millimeters; wing, 13.5 millimeters. Flagellar joints two and three yellowish towards the apex, remainder of flagellum light brown. The lateral abdominal stripe distinct from tergite three to eight. Ovipositor short, concolorous, viewed laterally upper valves almost circular, lower valves elliptic, the upper margin ending in a very fine, spine-like prolongation. 
Holotype, ơ , Victoria, British Columbia, July 6th, 1912. Allotype, o, topotypic.

Paratypes, 1 o', 6 o 옹, topotypic.

This species very closely resembles opisthocera. The wings are a trifle paler, likewise the stigma. The very different construction of the ninth tergite of the male, absolutely differentiates the two species. One male paratype has the thoracic stripes much less distinct.

\section{Tipula opisthocera spec. n.}

Testaceous; antennal flagellum unicolorous, fuscous. Thoracic stripes distinct. Pleural process conspicuous, strongly curved.

Male. Length, 12 millimeters; wing, 15 millimeters.

Head concolorous; frontal prolongation long, clothed with blackish hair, rather long on the nasus. Palpi brownish, the fourth joint darker and but little longer than the three preceding joints together. Face yellow. Antennæ slender, scapal joints yellow, first flagellar joint yellowish fuscous, joints subcylindrical, basal enlargement moderate with a whorl of rather long, black bristles; pubescense very fine, short, whitish. Front and occiput very dark fuscous, except near the base.

Thorax concolorous, shining. Praescutal stripes distinct, brown, rather broad and indistinctly margined with darker brown, the median stripe scarcely narrowed posteriorly, the lateral stripes much abbreviated in front, continued upon the scutum, where they leave but a narrow lateral stripe and a very narrow margin within, of the ground color. Scutellum and postnotum concolorous, lightly touched with fuscous. Pleura pale testaceous, with a faint, pale sheen. Legs yellowish-brown, densely clothed with brown hair; coxæ and base of femora paler, yellow; apices of femora and tibiæ fuscous, the latter longer than the metatarsi; tarsi fuscous. Halters concolorous, paler at base, club infuscate. Wings grayish with a fuscous tinge; vein $M$ and all the veins beyond the cord broadly margined with hyaline; costal cells a very faint yellow; stigma brown; the antestigmal spot extends into the base of cell M3, is faint beyond cell R1; a hyaline spot beyond the stigma. Rs, vein M and the apical veins except those limiting cell 1st M2, strongly setigerous.

Abdomen testaceous, paler towards the base; a fuscous dorsal stripe extends from the second tergite to the end of the seventh, becoming more diffused posteriorly; tergum indistinctly margined with fuscous, more accentuated in a dark spot on the anterior angles of tergites three to seven, a faint median ventral stripe. The eighth sternite clasping cephalad, narrowed and somewhat prolonged posteriorly, the caudal margin rather deeply emarginate, with a triangular appendage at each angle of the emargination, the latter filled with a whitish membrane, which has the appearance as though it consisted of matted hair. Hypopygium (Pl. V, Figs. 11 and 12) reddish-brown; ninth tergite rather narrow, directed obliquely dorsad, somewhat turgid, with a very deep oval emargination, the lateral angles prolonged, turgid, 
inclined inwardly, the inner margin with a large obtuse tooth and several smaller denticles. Ninth sternite very short, with slight medium notch. Pleural process long, somewhat flattened, twisted and appearing like an extended S. Apical appendages small and inconspicuous.

Female. Length, 12 millimeters; wing, 13.5 millimeters.

Antennæ shorter and more slender. Dorsal stripe of abdomen broader and more diffused posteriorly; the lateral stripes broad, strongly marked, tergites three to seven without lateral spots. Eighth segment entirely fuscous. Ovipositor dark testaceous, the upper valves short, quadrateoval, dark brown; lower valves paler, very small, scaphoidal.

Holotype, ơ , Sonoma County, California, April 20th, 1914.

Allotype, of topotypic.

Paratypes, $4 \sigma^{\top} \sigma^{\top}$ 's, 3 ㅇ o 's, topotypic.

A very distinct species. The ninth tergite of the male, with its deep, oval emargination, the sides thereof prolonged and strongly incurved with a large, obtuse point on its inner margin, distinguish this from the other species. The thoracic stripes are pronounced in all my specimens.

Tipula mutica spec. n.

Yellowish testaceous, shining. Antennal flagellum unicolorous. Thoracic stripes almost effaced. Pleural process twisted, curved, broad in basal portion.

Male. Length 12 millimeters; wing, 14 millimeters.

Head. Frontal prolongation and rostrum reddish-brown, with short, black hair. Palpi dark fuscous, joints two to four whitish at the base, the fourth joint scarcely as long as the preceding joints combined. Front and occiput grayish-fuscous, whitish along the upper orbital margin, a dark brown fronto-occipital stripe. Antennæ of moderate length, slender; first three joints pale yellow, remaining joints fuscous; basal enlargement of segments blackish with the usual whorl of setæ, the latter much shorter than the respective segments; pubescense fine, whitish.

Thorax concolorous, shining, the stripes faintly indicated, a shade darker than the ground color. Scutel and postnotum finely sericeous. Pleuræ pale yellow, faintly sericeous. Legs yellow, femora and tibiæ infuscate at the apex; the short, dense, black pilosity gives the legs a darker appearance; tibiæ distinctly longer than the metatarsi; tarsi fuscous. Halters pale fuscous, lighter towards the base, club dark fuscous. Wings pale gray, costal cells with a pale, yellow tinge, stigma pale yellowish-brown. Cell 1st M2 about twice as long as wide, veins brown, those beyond the cord broadly margined sub-hyaline, veins $\mathrm{M}$ and $\mathrm{Cu}$ less distinctly margined. The antestigmal spot is rather faint and does not extend beyond cell 1st M2; a faint hyaline spot beyond the stigma. $\mathrm{R} s$, veins $\mathrm{M}, \mathrm{Cu}, \mathrm{A}_{1}$ and apical veins setulose. 
Abdomen testaceous, shining; a well marked dorsal stripe extends from the first to the eighth tergite, a lateral fuscous stripe more or less interrupted, extends from the third to the sixth tergite, more accentuated in a darker spot near the anterior angle of the respective segments. Eighth sternite prolonged and narrowed posteriorly, the posterior margin with a broad, rounded emargination which is filled with a whitish membrane; each angle of the emargination bears a large, triangular appendage, the inner margin of which has a brush of short, dense, golden-yellow hair. Hypopygium (P1. V, Figs. 13 and 14) reddish, testaceous. The ninth tergite about as long as wide, broadly and deeply emarginate, the lateral angles prolonged as digitiform processes, slightly bent downward at the apex; the upper surface of the tergite with a median, longitudinal carina; viewed laterally, the upper surface appears subangulate about the middle. Ninth sternite short, with a median acute incision. Pleural suture complete, pleural process conspicuous, curved upward and markedly broadened just beyond the base, convoluted, then extending directly caudad and slightly bent outwardly. The outer apical appendages small, ovoidal, fringed with hair; the inner appendages a broad perpendicular lamina, extending above into an acutely pointed and strongly chitinized process; the lower margin strongly bearded with yellow, bristly hair.

Holotype, ๙ొ, Somona County, California, May 21, 1914. Paratypes, 4 우 오's, topotypic.

The formation of the hypopygium alone must be depended on for differentiation from allied species.

\section{Tipula streptocera-pallidocera var. n.}

A specimen in my collection received from Prof. Doane and bearing the label "L. streptocera," agrees in all details with the description and other specimens of this species, received or determined by its author, except that the antennæ are entirely pale yellowish. The thoracic stripes are ill defined.

Holotype, ๙̋, Keyport, Washington, July, 1905, (R. W. Doane). 


\section{EXPLANATION OF PLATE V.}

\section{Hypopygia.}

Fig. 1. Dorsal aspect of T. devia.

Fig. 2. Lateral aspect of $T$. devia.

Fig. 3. Dorsal aspect of $T$. fragmentata.

Fig. 4. Lateral aspect of $T$. fragmentata.

Fig. 5. Dorsal aspect of $T$. derbyi.

Fig. 6. Lateral aspect of $T$. derbyi.

Fig. 7. Dorsal aspect of T. monochroma, without apical appendages.

Fig. 8. Lateral aspect of $T$. monochroma.

Fig. 9. Dorsal aspect of T. trypetophora.

Fig. 10. Lateral aspect of T. trypetophora.

Fig. 11. Dorsal aspect of $T$. opisthocera.

Fig. 12. Lateral aspect of $T$. opisthocera.

Fig. 13. Dorsal aspect of $T$. mutica, without apical appendages.

Fig. 14. Lateral aspect of T. mutica.

Fig. 15. Dorsal aspect of $T$. streptocera, without apical appendages.

Fig. 16. Lateral aspect of $T$. streptocera. 


\section{$2 \mathrm{BHL}$ Biodiversity Heritage Library}

Dietz, W G. 1919. "The streptocera group of the dipterous genus Tipula Linnaeus." Annals of the Entomological Society of America 12, 85-93. https://doi.org/10.1093/aesa/12.2.85.

View This Item Online: $\underline{\text { https://www.biodiversitylibrary.org/item/43720 }}$

DOI: https://doi.org/10.1093/aesa/12.2.85

Permalink: https://www.biodiversitylibrary.org/partpdf/21999

\section{Holding Institution}

Smithsonian Libraries

\section{Sponsored by}

Smithsonian

\section{Copyright \& Reuse}

Copyright Status: NOT_IN_COPYRIGHT

This document was created from content at the Biodiversity Heritage Library, the world's largest open access digital library for biodiversity literature and archives. Visit BHL at https://www.biodiversitylibrary.org. 